\title{
Front Matter: Volume 7499
}

, "Front Matter: Volume 7499," Proc. SPIE 7499, Seventh Symposium Optics in Industry, 749901 (8 December 2009); doi: 10.1117/12.853274

SPIE Event: Seventh Symposium on Optics in Industry, 2009, Guadalajara, Jalisco, SPE. Mexico 


\title{
PROCEEDINGS OF SPIE
}

\section{Seventh Symposium Optics in Industry}

\author{
Guillermo García Torales \\ Jorge L. Flores Núñez \\ Gilberto Gómez Rosas \\ Eric Rosas \\ Editors
}

11-12 September 2009

Guadalajara, Jalisco, Mexico

Organized by

Universidad de Guadalajara (Mexico)

Coorganized by

Academica Mexicana de Óptica, A.C. (Mexico)

División de Óptica de la Sociedad Mexicana de Física, A.C. (Mexico)

Published by

SPIE

Volume 7499 
The papers included in this volume were part of the technical conference cited on the cover and title page. Papers were selected and subject to review by the editors and conference program committee. Some conference presentations may not be available for publication. The papers published in these proceedings reflect the work and thoughts of the authors and are published herein as submitted. The publisher is not responsible for the validity of the information or for any outcomes resulting from reliance thereon.

Please use the following format to cite material from this book:

Author(s), "Title of Paper," in Seventh Symposium Optics in Industry, edited by Guillermo García Torales, Jorge L. Flores Núñez, Gilberto Gómez Rosas, Eric Rosas, Proceedings of SPIE Vol. 7499 (SPIE, Bellingham, WA, 2009) Article CID Number.

ISSN 0277-786X

ISBN 9780819478108

Published by

SPIE

P.O. Box 10, Bellingham, Washington 98227-0010 USA

Telephone +1 3606763290 (Pacific Time) · Fax +1 3606471445

SPIE.org

Copyright (c) 2009, Society of Photo-Optical Instrumentation Engineers

Copying of material in this book for internal or personal use, or for the internal or personal use of specific clients, beyond the fair use provisions granted by the U.S. Copyright Law is authorized by SPIE subject to payment of copying fees. The Transactional Reporting Service base fee for this volume is $\$ 18.00$ per article (or portion thereof), which should be paid directly to the Copyright Clearance Center (CCC), 222 Rosewood Drive, Danvers, MA 01923. Payment may also be made electronically through CCC Online at copyright.com. Other copying for republication, resale, advertising or promotion, or any form of systematic or multiple reproduction of any material in this book is prohibited except with permission in writing from the publisher. The CCC fee code is 0277-786X/09/\$18.00.

Printed in the United States of America.

Publication of record for individual papers is online in the SPIE Digital Library.

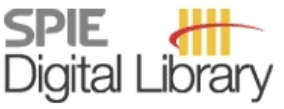

SPIEDigitalLibrary.org

Paper Numbering: Proceedings of SPIE follow an e-First publication model, with papers published first online and then in print and on CD-ROM. Papers are published as they are submitted and meet publication criteria. A unique, consistent, permanent citation identifier (CID) number is assigned to each article at the time of the first publication. Utilization of CIDs allows articles to be fully citable as soon they are published online, and connects the same identifier to all online, print, and electronic versions of the publication. SPIE uses a six-digit CID article numbering system in which:

- The first four digits correspond to the SPIE volume number.

- The last two digits indicate publication order within the volume using a Base 36 numbering system employing both numerals and letters. These two-number sets start with 00, 01, 02, 03, 04 , $05,06,07,08,09,0 \mathrm{~A}, 0 \mathrm{~B} \ldots \mathrm{OZ}$, followed by 10-1Z, 20-2Z, etc.

The CID number appears on each page of the manuscript. The complete citation is used on the first page, and an abbreviated version on subsequent pages. Numbers in the index correspond to the last two digits of the six-digit CID number. 


\title{
Contents
}

\author{
ix Symposium Committees \\ xi Introduction \\ xiii Symposium Sponsors
}

INSTRUMENTATION AND OPTICAL METROLOGY

749902 Analysis of explosives' precursors by means of a portable Raman spectrometer [7499-53] M. Del Río Anaya, G. García-Torales, V. Rodríguez Betancourtt, R. Rodríguez Rojas,

J. Flores Núñez, Univ. de Guadalajara (Mexico)

749903 Automation of a dynamic system to measure response of quartz crystal microbalance gas sensors [7499-47]

D. L. Osorio-Arrieta, S. Muñoz-Aguirre, G. Beltrán-Pérez, J. Castillo-Mixcóałl, Benemérita Univ. Autónoma de Puebla (Mexico); J. Rivera de la Rosa, Univ. Autónoma de Nuevo León (Mexico)

749904 Characterization of a multipoint sensor based on fiber Bragg gratings [7499-25]

O. Méndez Zepeda, S. Muñoz Aguirre, G. Beltrán Pérez, J. Castillo Mixcóatl, Benemérita Univ. Autónoma de Puebla (Mexico)

749905 Coherent photodetection with applications in quantum communications and cryptography [7499-15]

F. J. Mendieta, A. Arvizu, R. Muraoka, Ctr. de Investigación Científica y de Educación Superior de Ensenada (Mexico); P. Gallion, Telecom Paris Tech (France); J. Sanchez, Univ. Autónoma de Baja California (Mexico)

749906 Coherent techniques in optical wireless communications [7499-57]

J. D. Sanchez, Univ. Autónoma de Baja California (Mexico); A. Arvizu, F. J. Mendieta, Ctr. de Investigación Científica y de Educación Superior de Ensenada (Mexico)

749907 Circular polarization-splitting common-path interferometer based on a zero-twist liquid crystal display [7499-52]

J. A. Davis, B. M. L. Pascoguin, San Diego State Univ. (United States); I. Moreno, Univ. Miguel Hernández de Elche (Spain); A. Nava-Vega, Univ. Autónoma de Baja California (Mexico)

749908 Design and construction of a mechatronic robot with five degrees of freedom that locates internal porosity in centrifugal pumps [7499-61]

N. Bautista-Elivar, U. Uribe-Fernández, F. Ruiz-Conteras, D. Santillan-Gutierrez, C. Sánchez-Hernández, Polytechnical Univ. of Pachuca (Mexico); C. Robledo-Sánchez, Benemérita Univ. Autónoma de Puebla (Mexico)

749909 Determination of Hurst exponent by optical signal processing applied on surface roughness measurements [7499-04]

J. A. Marbán Salgado, O. Sarmiento Martínez, D. Mayorga Cruz, J. Uruchurtu Chavarín, Univ. Autónoma del Estado de Morelos (Mexico) 
7499 OA Development and implementation of photometric bench based on neutral optical density filters [7499-02]

L. P. González-Galván, R. A. Chávez-Velázquez, R. López-Ramírez, N. Vidal-Medina,

H. Zárate-Hernández, E. Rosas, Ctr. Nacional de Metrología (Mexico)

7499 OB Directional filters for fringe pattern denoising [7499-39]

J. Villa, Univ. Autónoma de Zacatecas (Mexico); J. A. Quiroga, Univ. Complutense de Madrid (Spain); I. de la Rosa, Univ. Autónoma de Zacatecas (Mexico)

7499 OC Discretization of quasi-sinusoidal diffraction gratings printed on acetates [7499-28] M. Mora-González, H. Pérez Ladrón de Guevara, J. Muñoz-Maciel, R. Chiu-Zarate, F. J. Casillas, G. Gómez-Rosas, F. G. Peña-Lecona, Z. M. Vázquez-Flores, Univ. de Guadalajara (Mexico)

7499 OD Effective UV radiation dose in polyethylene exposed to weather [7499-18] R. González-Mota, Instituto Tecnológico de Aguascalientes (Mexico); J. J. Soto-Bernal, I. Rosales-Candelas, Instituto Tecnológico de Aguascalientes (Mexico) and Ctr. de Investigaciones en Óptica, A.C. (Mexico); S. P. Calero Marín, Instituto Tecnológico de Aguascalientes (Mexico); J. T. Vega-Durán, Ctr. de Investigación en Ciencia Aplicada y Tecnología Avanzada, IPN (Mexico); R. Moreno-Virgen, Instituto Tecnológico de Aguascalientes (Mexico)

7499 OE Fast measurement of the refractive-index dispersion of dilute liquid solutions of absorbing molecules [7499-48]

E. Hernández-Sánchez, H. Contreras-Tello, C. Sánchez-Pérez, A. García-Valenzuela, Univ. Nacional Autónoma de México (Mexico)

7499 OF First-order design of off-axis reflective ophthalmic adaptive optics systems using afocal telescopes [7499-03]

A. Gómez-Vieyra, Ctr. de Investigaciones en Óptica, A.C. (Mexico); A. Dubra, Univ. of Rochester Eye Institute (United States); D. R. Williams, Univ. of Rochester (United States);

D. Malacara-Hernández, Ctr. de Investigaciones en Óptica, A.C. (Mexico)

7499 OG Gear inspection and reconstruction based on laser metrology and computer algorithms [7499-58]

I. Torres Contreras, Ctr. de Ingeniería y Desarrollo Industrial (Mexico);

J. Apolinar Muñoz Rodríguez, G. Garnica Campos, Ctr. de Investigaciones en Óptica, A.C. (Mexico)

$7499 \mathrm{OH}$ Itoh algorithm to unwrap 2D phase [7499-44]

G. Domínguez-Guzmán, J. Castillo-Mixcóatl, G. Beltrán-Pérez, S. Muñoz-Aguirre, Benemérita Univ. Autónoma de Puebla (Mexico)

7499 Ol Liquids sensor using Raman spectroscopy [7499-33]

A. E. Villanueva-Luna, J. Castro-Ramos, S. Vazquez-Montiel, Instituto Nacional de Astrofísica, Óptica y Electrónica (Mexico); A. Flores-Gil, Instituto Nacional de Astrofísica, Óptica y Electrónica (Mexico) and Univ. Autónoma del Carmen (Mexico); E. E. Orozco-Guillen, Univ. de Carabobo (Mexico) 
7499 OJ Method of analysis to measure the spherical power in ophthalmic lenses [7499-27] A. Bustillos-Trujillo, G. Trujillo-Schiaffino, D. P. Salas-Peimbert, P. G. Mendoza-Villegas, Instituto Tecnológico de Chihuahua (Mexico)

7499 OK Method of analysis to measure the tangential curvature in a test sphere [7499-21] P. G. Mendoza-Villegas, G. Trujillo-Schiaffino, D. P. Salas-Peimbert, A. Bustillos-Trujillo, Instituto Tecnológico de Chihuahua (Mexico)

7499 OL New paradigms in LED photometry and colorimetry [7499-14] A. Estrada-Hernández, L. P. González-Galván, E. Rosas, Ctr. Nacional de Metrología (Mexico)

7499 OM Novel automatic alignment of specialty optical fibers [7499-34] S. Salinas-Almaguer, V. Guzman-Ramos, C. Calles-Arriaga, L. Cortez-Gonzalez, R. Selvas, Univ. Autónoma de Nuevo León (Mexico)

7499 ON Optical characterization of the $62-\mathrm{cm}$ telescope at the Severo Diaz Galindo Observatory in Guadalajara [7499-36]

J. M. Nuñez, Univ. Nacional Autónoma de México (Mexico); E. de la Fuente, Univ. de Guadalajara (Mexico); E. Luna, J. Herrera, Univ. Nacional Autónoma de México (Mexico); E. Velazquez, F. García, Univ. de Guadalajara (Mexico); E. López, J. Váldez, B. García, B. Martínez, G. Guisa, F. Quiroz, E. Colorado, J. L. Ochoa, Univ. Nacional Autónoma de México (Mexico); J. Almaguer, A. Chávez, Univ. de Guadalajara (Mexico)

749900 Optical measurements of auto-excited oscillations [7499-45]

C. Pérez López, D. A. Gutiérrez Hernández, F. Mendoza Santoyo, Ctr. de Investigaciones en Óptica, A.C. (Mexico)

7499 OP Optimization of an optoelectronic system to detect volatile organic compound vapours [7499-20]

C. Martínez-Hipatl, S. Muñoz-Aguirre, J. Castillo-Mixcoatl, G. Beltrán-Pérez, Benemérita Univ. Autónoma de Puebla (Mexico)

$7499 \mathrm{OQ}$ Optomechatronic load cell validation according to the American standards [7499-42] F. J. Martínez Serrano, Univ. de la Salle Bajío (Mexico); A. A. Camacho P., Univ. de la Salle Bajío (Mexico) and CIATEC, A.C. (Mexico)

7499 OR Pressure monitoring over surfaces with sensitive paint by optical spectroscopy and intensity-based methods [7499-60]

G. García-Torales, Univ. de Guadalajara (Mexico); J. Castrellón-Uribe, Univ. Autonoma del Estado de Morelos (Mexico); E. Herrera Patiño, Univ. de Guadalajara (Mexico)

7499 OS Quantification of oxidation on the surface of a polymer through photography [7499-51] J. Yáñez M., A. Estrada M., CIATEC, A.C. (Mexico)

7499 OT Real-time turning surface inspection using laser light scattering [7499-10] A. Moreno-Báez, G. Miramontes de León, Ctr. de Investigación en Ciencia Aplicada y Tecnología Avanzada, IPN (Mexico) and Univ. Autónoma de Zacatecas (Mexico): F. Tenorio-Pérez, M. Ruiz-Torres, J. A. Huerta-Ruelas, Ctr. de Investigación en Ciencia Aplicada y Tecnología Avanzada, IPN (Mexico) 
7499 OU Reflectance difference laser measurements applied to the study of the stress/strain state in materials [7499-26]

C. H. Saucedo-Zárate, Ctr. de Investigación en Ciencia Aplicada y Tecnología Avanzada, IPN (Mexico) and Instituto Tecnológico de Aguascalientes (Mexico); M. López-López, Ctr. de Investigación y de Estudios Avanzados del IPN (Mexico); C. Sánchez-López, Instituto Tecnológico de Aguascalientes (Mexico); J. L. Correa-Figueroa, J. A. Huerta-Ruelas, Ctr. de Investigación en Ciencia Aplicada y Tecnología Avanzada, IPN (Mexico)

7499 OV Selection of the region of operation of an optical filter formed by two Sagnac interferometers in series through the use of retarding plates [7499-24]

A. Varguez Flores, G. Beltrán Pérez, S. Muñoz Aguirre, J. Castillo Mixcóatl, Benemérita Univ. Autónoma de Puebla (Mexico)

7499 OW Simulation of Fabry-Perot cavities in a Michelson interferometer [7499-55]

L. Aguilar-Lobo, C. Moreno, G. Garcia-Torales, Univ. de Guadalajara (Mexico)

7499 OX Size characterization of anatase $\mathrm{TiO}_{2}$ nanoparticles using a crystal size distribution in the LO Raman mode [7499-43]

H. Pérez Ladrón de Guevara, J. Castañeda Contreras, C. I. Medel Ruíz, C. G. Briseña Macias, Univ. de Guadalajara (Mexico)

7499 OY Spatial filtering and optical tomography of edge enhancement of a phase object [7499-46] A. Montes Pérez, C. Meneses Fabián, G. Rodríguez Zurita, Benemérita Univ. Autónoma de Puebla (Mexico)

7499 OZ Spectroscopic analysis of pharmaceutical formulations through the use of chemometric tools [7499-54]

N. Ornelas-Soto, O. Barbosa-García, M. Meneses-Nava, G. Ramos-Ortíz, J. Pichardo-Molina, J. L. Maldonado, U. Contreras, Ctr. de Investigaciones en Óptica, A.P. (Mexico);

L. López-Martínez, P. López-de-Alba, Univ. de Guanajuato (Mexico); F. López-Barajas, Ctr. de Investigaciones en Óptica, A.P. (Mexico)

749910 Twist-induced birefringence in fibers and optical rotation [7499-01]

D. Tentori, Ctr. de Investigación Científica y de Educación Superior de Ensenada (Mexico); C. Ayala-Díaz, Univ. Autónoma de Baja California (Mexico); F. Treviño-Martínez, Univ. Autónoma de Nuevo León (Mexico)

$749911 \quad$ Viability analysis of a dual gas sensor based on a single Fabry-Perot interferometer [7499-32] E. Vargas-Rodriguez, Univ. de Guanajuato (Mexico); D. A. May-Arrioja, Instituto Nacional de Astrofísica, Óptica y Electrónica (Mexico); J. M. Estudillo-Ayala, R. Rojas Laguna,

R. I. Mata-Chavez, E. Alvarado Mendez, Univ. de Guanajuato (Mexico)

749912 Young's modulus determination of a circular plate by ESPI [7499-31]

M. Farías, Univ. de Guanajuato (Mexico); R. Rodríguez-Vera, J. A. Rayas, Ctr. de Investigaciones en Óptica, A.C. (Mexico)

749913 Functional characterization of a liquid lens using a Zygo interferometer [7499-63] A. Santiago-Alvarado, Univ. Technólogica de la Mixteca (Mexico); S. Vázquez-Montiel, F. S. Granados-Agustín, J. Munoz-López, E. Percino-Zacarias, Instituto Nacional de Astrofísica, Óptica y Electrónica (Mexico); J. González-Garcia, Univ. Technólogica de la Mixteca (Mexico) 
749914 Design criteria for a multispectral, medium resolution, optical remote sensing system for nano-satellites [7499-64]

E. Pacheco, Ctr. de Investigación Científica y de Educación Superior de Ensenada (Mexico) and Univ. of Surrey (United Kingdom); F. J. Mendieta, R. Muraoka, Ctr. de Investigación Científica y de Educación Superior de Ensenada (Mexico);

J. de Dios Sánchez, Univ. Autónoma de Baja California (Mexico)

\section{LASERS IN INDUSTRY}

749915 Comparison of a Joule effect calibration system using Kanthal wire and a laser diode as heat sources [7499-35]

B. A. Maldonado, M. Bárcena-Soto, N. Casillas, J. L. Flores, Univ. de Guadalajara (Mexico)

749916 Complex optical microcomponents for integrated-optic applications fabricated by laser ablation [7499-06]

G. V. Vázquez, Ctr. de Investigaciones en Óptica, A.C. (Mexico) and Ecole Polytechnique de Montreal (Canada); A. Harhira, R. G. Bosisio, R. Kashyap, Ecole Polytechnique de Montreal (Canada)

749917 Glass doped with semiconductor nanoparticles for optical devices [7499-29]

E. Rodriguez, L. Ponce, M. Arronte, E. de Posada, Ctr. de Investigación en Ciencia Aplicada y Tecnología Avanzada, IPN (Mexico); G. Kellerman, Lab. Nacional de Luz Sincrotron (Brazil); C. L. César, L. C. Barbosa, Univ. Estadual de Campinas (Brazil)

749918 Laser induced micro-cracks formation inside the glass, LIBS, and PILA measurements [7499-22]

R. Reynaud, L. V. Ponce, M. A. Arronte, E. de Posada, E. Rodríguez, T. Flores, Ctr. de Investigación en Ciencia Aplicada y Tecnología Avanzada, IPN (Mexico)

749919 Modes in a long period grating fabricated on dispersion shifted fiber [7499-07]

J. A. Estrada-Ramírez, R. I. Mata-Chávez, Univ. de Guanajuato (Mexico); A. Martínez-Rios, Ctr. de Investigaciones en Optica, A.C. (Mexico); J. M. Estudillo-Ayala, R. Rojas-Laguna, E. Vargas-Rodríguez, E. Alvarado-Méndez, J. Amparo Andrade-Lucio, Univ. de Guanajuato (Mexico)

7499 1A Multidirectional tunable wave resonators [7499-08]

J. A. Méndez-Bermúdez, Benemérita Univ. Autónoma de Puebla (Mexico); C. Tapia-Ignacio, Univ. Autónoma del Estado de Hidalgo (Mexico); G. A. Luna-Acosta, Benemérita Univ. Autónoma de Puebla (Mexico)

7499 1B On the Nd:YAG pulsed laser processing of rigid PVC [7499-12]

L. C. Hernández, Univ. of Havana (Cuba); M. Arronte, L. Ponce, T. Flores, J. Guerrero,

E. de Posada, E. Rodríguez, Ctr. de Investigación en Ciencia Aplicada y Tecnología Avanzada, IPN (Mexico)

7499 1C Solutions for stability and astigmatism in high power laser resonators [7499-11] R. Narro, M. Arronte, E. de Posada, L. Ponce, E. Rodríguez, Ctr. de Investigación en Ciencia Aplicada y Tecnología Avanzada, IPN (Mexico) 
7499 1D Surface structure changes in cement paste exposed to $10.6 \mu \mathrm{m}$ laser radiation [7499-62] J. J. Soto-Bernal, Instituto Tecnológico de Aguascalientes (Mexico) and Ctr. de Investigaciones en Optica, A.C. (Mexico); M. R. Moreno-Virgen, Instituto Tecnológico de Aguascalientes (Mexico) and Ctr. de Investigación en Ciencia Aplicada y Tecnología Avanzada, IPN (Mexico); C. Frausto-Reyes, Ctr. de Investigaciones en Óptica, A.C. (Mexico); A. Bonilla-Petriciolet, Instituto Tecnológico de Aguascalientes (Mexico); J. T. Vega-Durán, J. Pineda-Piñón, Ctr. de Investigación en Ciencia Aplicada y Tecnología Avanzada, IPN (Mexico); J. A. Ortiz-Lozano, Univ. Autónoma de Aguascalientes (Mexico)

\section{BIOTECHNICAL PROCESS}

7499 IE Online analysis of sulfur in diesel line by a monochromatic wavelength dispersive x-ray fluorescence spectrometry [7499-19]

E. Pérez-Careta, Refinery Ing. Antonio M. Amor (Mexico) and Univ. de Guanajuato (Mexico);

J. A. López-Ramírez, G. Reynoso-Whitaker, Refinery Ing. Antonio M. Amor (Mexico);

J. Sánchez-Mondragon, Instituto Nacional de Astrofísica, Óptica y Electrónica (Mexico);

M. Torres-Cisneros, Univ. de Guanajuato (Mexico)

7499 IF Optical temperature behavior of a starch-water mixture [7499-17]

J. de Dios Ortiz-Alvarado, Ctr. de Investigación en Ciencia Aplicada y Tecnología

Avanzada, IPN (Mexico); B. Yahuaca-Juárez, Univ. Michoacana de San Nicolás de Hidalgo (Mexico); P. Vázquez-Landaverde, E. Morales-Sánchez, Ctr. de Investigación en Ciencia

Aplicada y Tecnología Avanzada, IPN (Mexico); H. E. Martínez-Flores, Univ. Michoacana de San Nicolás de Hidalgo (Mexico); A. Canto-Pérez, J. A. Huerta-Ruelas, Ctr. de Investigación en Ciencia Aplicada y Tecnología Avanzada, IPN (Mexico)

\section{SOLAR ENERGY}

7499 IG Solar cells based on organic molecules and polymers [7499-23]

J. F. Salinas, J. L. Maldonado, G. Ramos-Ortíz, M. Rodríguez, M. A. Meneses-Nava, O. Barbosa-García, Ctr. de Investigaciones en Óptica, A.P. (Mexico); N. Farfán, Univ. Nacional Autónoma de México (Mexico); R. Santillan, Ctr. de Investigación y de Estudios Avanzados del IPN (Mexico)

Author Index 


\title{
Symposium Committees
}

\author{
Conference Chair
}

Guillermo García Torales, Universidad de Guadalajara (Mexico)

National Advisory Council

Eric Rosas, Academia Mexicana de Óptica (Mexico)

Sergio Vázquez y Montiel, División de Optica de la Sociedad Mexicana de Física (Mexico)

Víctor Gónzález Álvarez, Universidad de Guadalajara (Mexico)

Organizing Committee

Guillermo García Torales, Universidad de Guadalajara (Mexico) Jorge Luis Flores Núñez, Universidad de Guadalajara (Mexico) Gilberto Gómez Rosas, Universidad de Guadalajara (Mexico)

National Scientific Committee

Guillermo García Torales, CUCEl, Universidad de Guadalajara (Mexico) Jorge Luis Flores Núñez, CUCEl, Universidad de Guadalajara (Mexico) Gilberto Gómez Rosas, CUCEl, Universidad de Guadalajara (Mexico) Brenda Esmeralda Martínez Zérega, CULAGOS, Universidad de Guadalajara (Mexico)

Gerardo Peña Lecona, CULAGOS, Universidad de Guadalajara (Mexico) Rubén Rodríguez Rojas, CULAGOS, Universidad de Guadalajara (Mexico)

Rufino Díaz Uribe, CCADET, Universidad Nacional Autónoma de México (Mexico)

Eric Rosas, Centro Nacional de Metrología (Mexico)

Alejandra Alicia Silva Moreno, CIATEC (Mexico)

Francisco J. Ornelas Rodriguez, CICATA, Instituto Politécnico Nacional (Mexico)

Juan B. Hurtado Ramos, CICATA, Instituto Politécnico Nacional (Mexico) Josué Álvarez Borrego, CICESE (Mexico) Jesús Castrellón Uribe, CIICAP, Universidad Autonoma del Estado de Morelos (Mexico)

Francisco Javier Cuevas de la Rosa, ClO (Mexico)

Geminiano Martínez Ponce, $\mathrm{ClO}$ (Mexico)

Elder De la Rosa Cruz, $\mathrm{ClO}$ (Mexico)

Fermín S. Granados Agustín, INAOE (Mexico)

Juan José Soto Bernal, ITA (Mexico)

Julio César Gutiérrez Vega, ITESM (Mexico)

Ricardo Legarda Saenz, UADY (Mexico)

Jesús Villa Hernández, UAZ (Mexico) 
Claudia Sifuentes Gallardo, UAZ (Mexico)

Iván Moreno, UAZ (Mexico)

International Scientific Committee

Diana Tentori Santa Cruz, CICESE (Mexico)

Fernando Mendoza Santoyo, $\mathrm{ClO}$ (Mexico)

Alejandro Cornejo Rodríguez, INAOE (Mexico)

Jose A. Ferrari, Universidad de la República (Uruguay)

Erna Frins, Universidad de la República (Uruguay)

Yobani Mejía, Universidad Nacional de Bogotá (Colombia)

José Luis Ocaña Moreno, Universidad Politécnica de Madrid (Spain)

Carlos Molpeceres Álvarez, Universidad Politécnica de Madrid (Spain)

Antonio Quiroga Mellado, Universidad Complutense de Madrid (Spain) 


\section{Introduction}

The Seventh Symposium Optics in Industry (VII SOI) was held 11-12 September 2009 in Guadalajara, Jalisco, Mexico. Many conference attendees enjoyed the interesting talks of the symposium, exchanged knowledge, ideas and experiences with scientists, young researchers and students, from both the academic and industrial sectors in the field of optics, science, and technology.

The Universidad de Guadalajara was honored as the host institution of the VII SOI. This seventh edition of the SOl allowed those who apply the optical technology to meet their developers and join their efforts towards the identification of strategic areas for development and towards the immediate solution of the problems in industry. The symposium also allowed the attendees the opportunity to look for the applications of optics in the saving energy processes, biotechnological issues, and the optical instrumentation around it.

In the VII SOI, authors from the countries of Brazil, Canada, Cuba, Spain, United States of America, Uruguay, Venezuela, and Mexico presented over 80 poster contributions; these proceedings contain a selection of those papers. The attendees also learned of the success cases in the optical industry in Guadalajara such as MIXBAAL, CONTINENTAL Guadalajara, and PEMEX.

Likewise, during the VII SOI we had the opportunity of listening to eight invited talks given by important members of Mexican, international and foreign industry, academic, and government organizations such as The Optical Society of America (OSA), the Breault Research Organization, the National Aeronautics and Space Administration (NASA), the Universidad Politécnica de Madrid, the Centro Nacional de Metrología (CENAM), Centro de Investigaciones en Óptica (ClO), the Instituto Nacional de Óptica, Astrofísica y Electrónica (INAOE), CONTINENTAL Guadalajara, the Fideicomiso para el Ahorro de la Energía Eléctrica (FIDE), the Consejo Estatal de Ciencia y Tecnología del Estado de Jalisco (COECYTJAL), the Optical Science College, and SPIE.

As a part of the activities for the symposium, the organizing committee offered some hands-on workshops in optical fields with wide application in the industry, and some SPIE Mexican student chapters had a one day meeting as a parallel activity along the symposium. The activities of both days closed with a discussion panel on the topic of the day, the definition of strategic development areas in optics for supporting Mexico's efforts in developing alternative energy sources and biotechnology, and the mechanisms for the integration of science and industry in optics.

On behalf of the Universidad de Guadalajara, the Academia Mexicana de Óptica, A.C. and the División de Óptica de la Sociedad Mexicana de Física, 
A.C., we want to kindly acknowledge the attendants and sponsors for all your valuable participation and support to the VII Symposium Optics in Industry, especially in a year of much global economic hardship. We wish to express our gratitude to the participants for making the extra effort of coming to the symposium and hope you enjoyed your stay in Guadalajara, Jalisco, Mexico.

\section{Guillermo García Torales Jorge L. Flores Núñez Gilberto Gómez Rosas Eric Rosas}




\section{SOI Sponsorship}

Organized by:

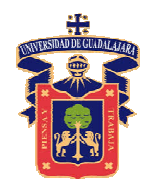

Coorganized by:

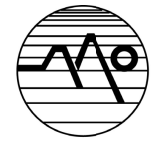

ACADEMIA MEXICANA
DE ÓPTICA, A.C.

SMF

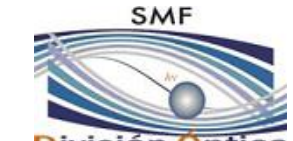

División Ōptica

With the help of:

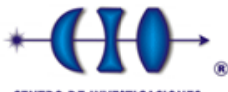
CENTRO DE INVESTIGACIONES EN OPTICA, A.C.

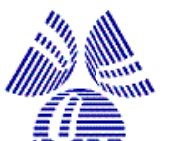

infoe

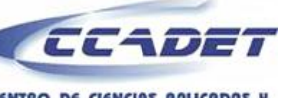

CENTRO DE CIENCINS RPUCAPAS
DESARROULO TECMOLOGICO
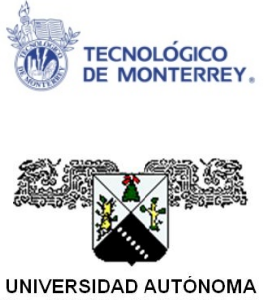

UNIVERSIDAD AUTÓNOMA
DEL ESTADO DE MORELOS

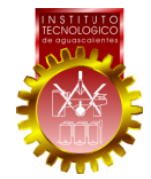

Centro Universitario de Ciencias Exactas e

Ingenierías, Universidad de Guadalajara

Academia Mexicana de Óptica, A. C.

División de Óptica, Sociedad Mexicana de Física, A. C.
Centro de Investigaciones en Óptica, A. C.

Instituto Nacional de Astrofísica, Óptica y Electrónica

Centro de Ciencias Aplicadas y Desarrollo Tecnológico, Universidad Nacional Autónoma de México

Centro de Óptica, Tenológico de Monterrey

Universidad Autónoma del Estado de Morelos

Instituto Tecnológico de Aguascalientes
15 aniversario S CENAM CENTRO NACIONAL DE METROLOGIA
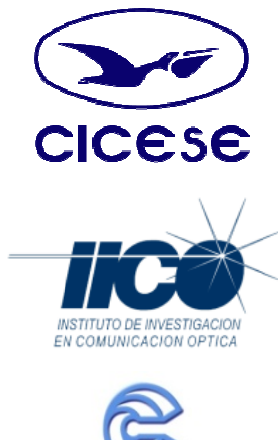

CIATEC
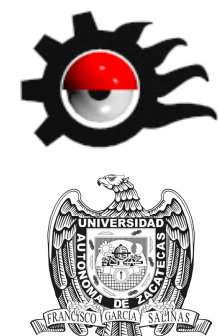

Centro Nacional de Metrología

Centro de Investigación Científica y de Educación Superior de Ensenada

Instiuto de Investigación en Comunicación Óptica, Universidad Autónoma de San Luis Potosí

Centro de Innovación Aplicada en Tecnologías Competitivas, A. C.

Centro de Investigación en Ciencia Aplicada y Tecnología Avanzada, Instituto Politécnico Nacional

Universidad Autónoma de Zacatecas 


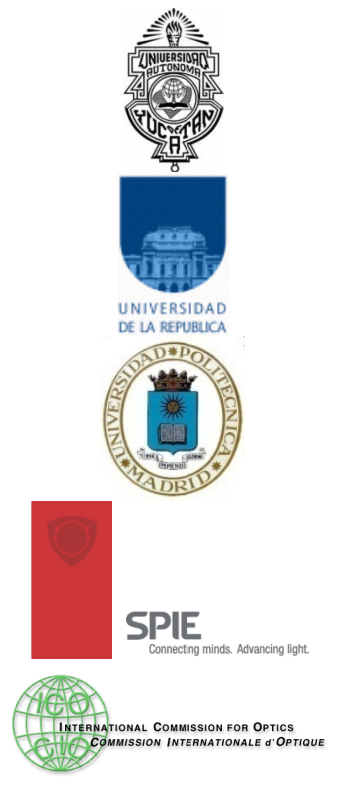

Universidad Autónoma de
Yucatán

Universidad de la República de Uruguay

Universidad Politécnica de Madrid

SPIE

Comité Territorial de Óptica de México, International Commission for Optics
Universidad Autónoma del Estado de México

Universidad Nacional de Colombia

Universidad Complutense de Madrid

The Optical Society of America

The Optical Society

RIAO $\begin{gathered}\text { Red liberamericana de } \\ \text { Opica }\end{gathered}$

Sponsored by:

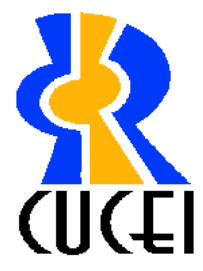

Centro Universitario de Ciencias Exactas e Ingenierías

(CUCEI),

Universidad de Guadalajara,

Blvd. Marcelino García Barragán 1421, esq. Calzada

Olímpica. Guadalajara, Jalisco, México. C. P. 44430

Tel.: ++52 (33) 1378-5900/ Fax: 3942-5924

http://www.cucei.udg.mx/

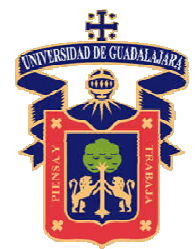

Coordinación General Académica (CGA),

Universidad de Guadalajara,

Av. Juárez Nº 976 (pisos 7 y 8) S. J. Guadalajara,

Jalisco México C. P. 44100

Tel.: ++ 52 (33) 3134-4657

http://www.cga.udg.mx/

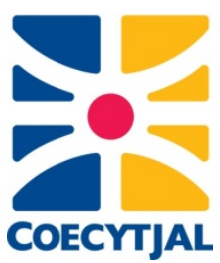

Consejo Estatal de Ciencia y Tecnología de Jalisco (COETCYTJAL)

López Cotilla 1505 Torre Seproe 2do. Piso, Col.

Americana. Guadalajara, Jalisco, México.

Tel.: ++52 (33) 3585-6599 / 3585-6601

http://www.coecytjal.org.mx/

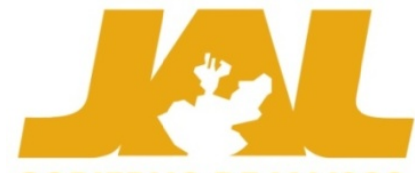

GOBIERNO DE JALISCO
Gobierno de Jalisco

Palacio de Gobierno, Colonia Centro, C. P. 44100

Guadalajara, Jalisco, México.

Tel.: ++52 (33) 3668-1804

http://www.jalisco.gob.mx/ 


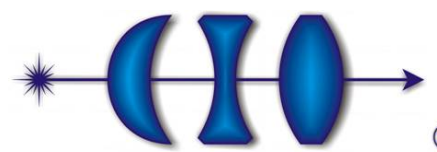

\section{CENTRO DE INVESTIGACIONES EN OPTICA, A.C.}

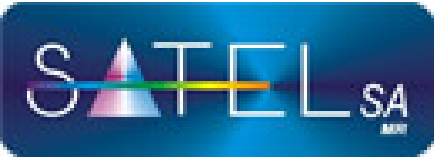

Centro de Investigaciones en Óptica, A. C.

Loma del Bosque \#115,Col. Lomas del Campestre.

(®) León, Gto., México. C. P. 37150 A.P. 1-948

Tel.: ++52 (477) 441-4200 / Fax: (477) 441-4209

http://www.cio.mx/

Sistemas y Aplicaciones de Telecomunicaciones

Blvd. Bernardo Quintana 20-6. Colonia Álamos, 2da.

Sección. Querétaro Qro. México. C. P. 76160.

Tel.: ++52 (442) 295-2600 al 03

http://www.satelsa.com.mx/

National Instruments

Av. Lincoln No. 1355, Local 2, Col. La Playa. Ciudad Juárez, Chih., México. 32317

Tel.: 018000100793 / Fax: 656 686-0358

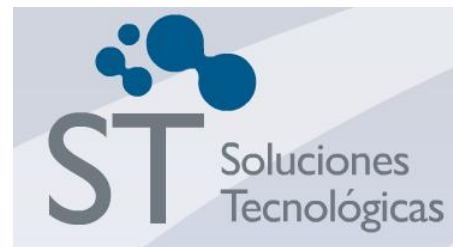

Soluciones Tecnológicas

Av. Adolfo López Mateos Sur 2077 Int. Z15,

Col. Jardines Plaza del Sol, C. P. 44510.

Guadalajara, Jalisco. México

Tel.: ++52 (33) 3030-7170

info@st-mx.com

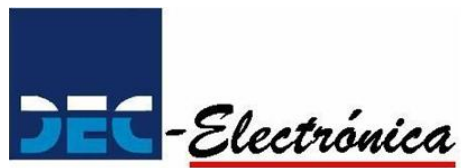

DEC-Electrónica

Guadalajara, Jalisco, México.

Tel.: ++52 (33) 3614-4222 / 01-800-777-0723

Fax: ++52 (33) 3613-5899

http://www.dec-electronica.com.mx/

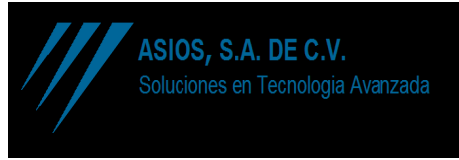

Asios,

Camino Real al Ajusco No. 29

Col. Ampliacion Tepepan, C. P. 16029 Xochimilco

Mexico, D.F.

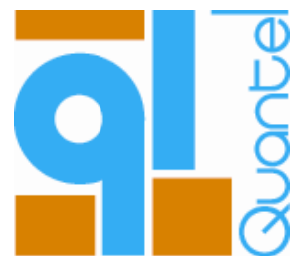

Quantel Medical

601 Haggerty Lane, Bozeman-Montana 59715, USA.

Phone: +1 888660 6726, Fax: +1 4065222005

http://www.quantel-medical.com/

MIXBAAL

Av. Periferico Sur No 7980-3B

Santa María Tequepexpan

Tel. ++52 (33) 3133-4515, Fax: ++52 (33) 3133-4511

MIXBAAL

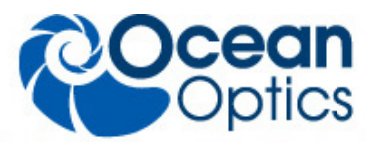

Ocean Optics, México

Fermin Riestra 1485, Interior - 203 Col. Moderna

Guadalajara, Jal. C. P. 44190

Tel./Fax: ++52 (33) 3812-1694 
Downloaded From: https://www.spiedigitallibrary.org/conference-proceedings-of-spie on 26 Apr 2023

Terms of Use: https://www.spiedigitallibrary.org/terms-of-use 